\title{
Duo-moederschap in Nederland vanuit juridisch en ontwikkelingspsychologisch perspectief
}

\author{
Henny Bos ${ }^{1}$ en Machteld Vonk ${ }^{2}$
}

\section{$1 \quad$ Inleiding}

In het midden van de jaren tachtig van de vorige eeuw begonnen ziekenhuizen en fertiliteitklinieken in Nederland en België, maar ook in de Verenigde Staten en Engeland, hun diensten in infertiliteitafdelingen open te stellen voor (vrouwelijke) paren van gelijk geslacht. Hierdoor werd het voor lesbische vrouwen mogelijk om middels een in het ziekenhuis uitgevoerde spermadonatie zwanger te worden, kinderen te krijgen en al dan niet samen met een vrouwelijke partner een gezin te stichten. In de Engelstalige literatuur worden deze gezinnen ook wel aangeduid met 'planned lesbian families'. ${ }^{3}$ Deze term wordt gebruikt om hen te onderscheiden van de gezinnen waarin lesbische moeders kinderen opvoeden die in een eerdere heteroseksuele relatie van één van beiden of beide moeders zijn geboren.

Hoewel het niet exact duidelijk is hoeveel vrouwen gebruik hebben gemaakt van de mogelijkheid om middels spermadonatie een kind te krijgen, werd er toch al snel gesproken van een 'lesbische babyboom'. ${ }^{4}$ Ook nu (anno 2012) is het niet duidelijk om hoeveel gezinnen het precies gaat. Uit recente gegevens van het Centraal Bureau voor Statistiek blijkt dat er in 2009 in Nederland ongeveer 25.000 samenwonende vrouwelijke koppels zijn. In de huishoudens van $20 \%$ van de vrouwelijke paren zijn kinderen onder de 18 jaar aanwezig. ${ }^{5}$ Naar verwachting zal in Nederland het aantal kinderen dat van het begin af aan wordt opgevoed door twee moeders in de toekomst toenemen. ${ }^{6}$ Uit een recent onderzoek in Nederland in opdracht van het Sociaal Cultureel Planbureau uitgevoerd onderzoek onder 1.101 jonge meiden (tussen 16 en 24 jaar oud) die zichzelf lesbisch noemen of zeggen gevoelens voor hetzelfde geslacht te hebben, bleek dat $60 \%$ van de meisjes een kinderwens heeft. ${ }^{7}$

\footnotetext{
${ }^{1}$ Dr. Henny Bos is als universitair docent en onderzoeker werkzaam bij de afdeling Pedagogische en Onderwijskundige Wetenschappen en de Leraren Opleiding (POWL) van de Universiteit van Amsterdam. Van Februari 2012 tot en met Juni 2012 is zij als 'visiting scholar' verbonden aan het Williams Institute, School of Law, University of California - Los Angeles (Los Angeles, USA).

${ }^{2}$ Dr. Machteld Vonk is als universitair docent en onderzoeker familie- en jeugdrecht werkzaam bij de rechtenfaculteit van de Universiteit Leiden bij de afdeling Jeugdrecht.

${ }^{3}$ Golombok, Parenting: What really counts?, New York: Routledge, 2000.

${ }^{4}$ Patterson, Families of the lesbian baby boom: Maternal mental health and child adjustment, Journal of Gay and Lesbian Psychotherapy, 2001, 91, 107.

${ }^{5}$ Bos \& Van Gelderen, Homo en lesbisch ouderschap in Nederland. In S. Keuzenkamp (ed.), Steeds gewoner, nooit gewoon. Acceptatie van homoseksualiteit in Nederland (pp. 104-118), Den Haag: Sociaal en Cultureel Planbureau, 2010.

${ }^{6}$ OCW , Paars over Roze. Nota homo emancipatie, Den Haag: Ministerie van Onderwijs Cultuur en Wetenschap, 2001.

${ }^{7}$ Van Bergen \& Van Lisdonk, Psychisch welbevinden en zelfacceptatie van homojongeren, in Keuzenkamp (ed.), Steeds gewoner, nooit gewoon. Acceptatie van homoseksualiteit in Nederland (pp. 174-196), Den Haag: Sociaal en Cultureel Planbureau, 2010.
} 
De Nederlandse wetgever heeft de afgelopen jaren geprobeerd de wetgeving op het gebied van ouder-kind relaties aan te passen aan de maatschappelijke ontwikkelingen ten aanzien van lesbisch en homoseksueel ouderschap. $\mathrm{Na}$ de introductie van het geregistreerd partnerschap in 1998 en later de openstelling van het huwelijk voor paren van gelijk geslacht in 2001, is er vrijwel continu discussie geweest over de afwijkende rechtspositie van kinderen die binnen gelijkgeslachtelijke relaties worden geboren. Kinderen geboren binnen een huwelijk van twee vrouwen, hebben, in tegenstelling tot kinderen geboren binnen een man-vrouw huwelijk, niet automatisch twee juridische ouders. ${ }^{8}$ Onder het huidige recht is het voor de duo-moeder - de vrouwelijke partner van de geboortemoeder - weliswaar mogelijk om via adoptie juridisch ook de ouder te worden, maar dat kan alleen via een juridische procedure waarin de bekende donor met family life ook een rol van betekenis kan spelen. ${ }^{9}$

Voor homoseksuele mannen paren met een kinderwens ligt het allemaal veel ingewikkelder. ${ }^{10}$ Het Nederlandse afstammingsrecht is zo ingericht dat de vrouw uit wie het kind wordt geboren de juridische moeder is. Dit betekent dat een kind altijd binnen de relatie van die moeder wordt geboren (indien zij een relatie heeft) en nooit binnen de relatie van twee mannen kan worden geboren. Afhankelijk van de manier waarop de mannen hun ouderschap vorm willen geven, zijn ze in beginsel aangewezen op draagmoederschap, adoptie of co-ouderschap. Alle drie deze opties zijn complex en kennen hun eigen onzekerheden. Draagmoederschap is in Nederland op zichzelf niet verboden, maar de juridische overdacht van het ouderschap van de moeder naar de wensvaders is niet apart geregeld. ${ }^{11}$ Adoptie is veelal moeilijk omdat er in Nederland zelf weinig kinderen ter adoptie worden afgestaan. Richten mannen paren hun hoop op het buitenland, dan blijkt ook deze weg ingewikkeld en onzeker te zijn. ${ }^{12}$ Voor Nederlandse mannenparen met een kinderwens is dan ook de meest voor de hand liggende optie om sperma te doneren aan een lesbisch stel (of aan een alleenstaande lesbische of heteroseksuele vrouw) en in een co-ouderschap constructie samen met de moeder(s) de opvoeding van het kind te delen. ${ }^{13}$ Co-ouderschap tussen een lesbisch en homoseksueel stel, wordt het ook wel een 'meer-ouderschapssituatie' genoemd. ${ }^{14}$

\footnotetext{
${ }^{8}$ Vonk, One, two or three parents? Lesbian co-mothers and a known donor with 'family life' under Dutch Law, International Journal of Law, Policy and the Family, 2004, 18, 103-117.

${ }^{9}$ Zie de artikelen 1:277 tot en met 1:230 BW.

${ }^{10}$ Curry-Sumner en Vonk, Adoptie: wie probeert de wet te beschermen, Tijdschrift voor familie- en jeugdrecht, 2006/12.

${ }_{11}$ Boele-Woelki, Curry-Sumner, Schrama en Vonk, Draagmoederschap en illegale opneming van kinderen, Den Haag: WODC, 2011.

${ }^{12}$ Curry-Sumner en Vonk, It all depends on who you ask: Dutch parentage law in four acts, in Atkins (ed.), The international survey of family law 2009 edition (pp 329-352), Bristol: Jordan Publishing, 2009.

${ }^{13}$ Bos \& Hakvoort, Child adjustment and parenting in planned lesbian families with known and as-yet unknown donors, Journal of Psychosomatic Obstetrics \& Gynecology, 2007, 28, 121-129 en Bos, Planned gay father families in kinship arrangements. Australian and New Zealand Journal of Family Therapy, 2010, 31, 356-371.

${ }^{14}$ Vonk, One, two or three parents? Lesbian co-mothers and a known donor with 'family life' under Dutch Law, International Journal of Law, Policy and the Family, 2004, 18, 103-117.
} 
In dit artikel wordt aandacht besteed aan duo-moederschap in Nederland vanuit een ontwikkelingspsychologisch/pedagogisch en een juridisch perspectief. Allereerst wordt aandacht besteed aan de huidige juridische situatie en de ontwikkelingen die zich recent daarin hebben voorgedaan. Uit deze bespreking rijst een aantal vragen met betrekking tot de relatie tussen de duo-moeders, het kind en de (on)bekende donor, die vervolgens vanuit ontwikkelingspsychologisch perspectief worden besproken. In het laatste deel van het artikel wordt aandacht besteed aan de voorgestelde wetgeving met betrekking tot de positie van het kind in een gezin met twee moeders, waarbij aan de hand van de ontwikkelingspsychologische bevindingen wordt gekeken naar de kwaliteit van het voorstel.

\section{$2 \quad$ Duo-moederschap anno 2012}

Sinds de invoering van het geregistreerd partnerschap in 1998 is een aantal wettelijke bepalingen met betrekking tot gezag en adoptie gewijzigd om het sociaal ouderschap van de vrouwelijke partner van de geboortemoeder een juridische basis te geven. Uitganspunt daarbij is geweest de gelijke behandeling van paren van gelijk geslacht en de bescherming van het gezin waarin het kind opgroeit. Er is tot nu toe gekozen om alleen de wettelijke regeling omtrent gezag en adoptie te wijzigen; het afstammingsrecht is ongewijzigd gebleven en is nog steeds gebaseerd op het gegeven dat een kind een moeder heeft en een vader kan hebben. De meest recente wijziging betreft een versoepeling van de adoptieprocedure voor de vrouwelijke partner van de geboortemoeder in 2009.

De strategie om gelijkstelling tussen kinderen van lesbische paren en kinderen van heteroseksuele paren via een versoepeling van de adoptieregeling te bewerkstelligen, is van het begin af aan onderwerp geweest van kritiek. Tijdens de parlementaire behandeling van de huidige adoptieregeling heeft de Raad van State in zijn advies te kennen gegeven dat adoptie niet de juiste manier is om gestalte te geven aan het ouderschap van de niet-biologische moeder, maar dat dit eerder moet worden gezocht in een vorm van erkenning. ${ }^{15}$ Naar aanleiding van deze bevindingen en een daaropvolgend door Pechtold c.s. begin 2007 ingediende motie, ${ }^{16}$ is in mei 2007 de Commissie Kalsbeek ingesteld met de opdracht om 'te bezien op welke andere wijze dan door adoptie (...) kan worden voorzien in een mogelijkheid voor de vrouwelijke partner van de moeder om op eenvoudige wijze ouder te worden van het kind, geboren binnen de relatie van deze vrouw en de moeder'. ${ }^{17}$

Op 31 oktober 2007 heeft de Commissie Kalsbeek haar rapport uitgebracht. De Commissie was kort samengevat van mening dat het in ieder geval mogelijk moet worden voor een niet-biologische moeder om het kind van haar vrouwelijke partner te erkennen. De Commissie gaf echter geen antwoord op de vraag of ook het ouderschap van rechtswege mogelijk moet zijn indien het lesbische paar gehuwd is, hetgeen

\footnotetext{
${ }^{15}$ Zie Kamerstukken II 2005-06, 30 551, nr. 4, p. 3.

${ }^{16}$ Zie Kamerstukken II 2006-07, 30800 VI, nr. 60.

${ }^{17}$ Zie Kamerstukken II 2006-07, 30 551, nrs. 8 en 9.
} 
overigens niet betekent dat de Commissie in haar rapport geen aandacht aan de implicaties van deze mogelijkheid heeft besteed. De twee uitgangspunten die de Commissie heeft gehanteerd zijn enerzijds het belang van het kind bij een stabiele opvoedingssituatie en anderzijds het belang van het lesbische paar bij gelijke behandeling. In zijn reactie heeft de Minister aangekondigd een wetsvoorstel te willen voorbereiden met de volgende strekking: lesbische partners die een huwelijk of een geregistreerd partnerschap met elkaar zijn aangegaan en gebruik hebben gemaakt van een onbekende donor, worden beide van rechtswege juridisch moeder van het kind dat binnen hun huwelijk of geregistreerd partnerschap wordt geboren. Dat ze gebruik hebben gemaakt van een onbekende donor zou moeten blijken uit een verklaring van de Stichting Donor Gegevens Kunstmatige Voortplanting. Voor lesbische paren die geen huwelijk of geregistreerd partnerschap zijn aangegaan en lesbische paren die gebruik hebben gemaakt van een bekende donor, zal de mogelijkheid van erkenning door de niet-biologische moeder mogelijk worden gemaakt. Echter voordat de Minister daadwerkelijk tot het indienen van een wetsvoorstel zou overgaan, wilde hij eerst dat nader onderzoek werd verricht naar de juridische positie van de bekende donor met family life en de rechten van het kind met betrekking tot zijn afstammingsgegevens.

Ondanks al deze ontwikkelingen is het wetvoorstel om de adoptieregeling te versoepelen aangenomen en op 1 januari 2009 in werking getreden. ${ }^{18}$ De stand van zaken met betrekking tot adoptie door de niet-biologische moeder is op dit moment als volgt: voor de adoptie door de niet-biologische moeder is niet langer vereist dat het lesbische paar voorafgaand aan indiening van het verzoek enige jaren heeft samengewoond. Bovendien is het door de recente wetswijziging mogelijk om al voor de geboorte van het kind een verzoek tot adoptie in te dienen. Wordt dit verzoek na de geboorte toegewezen dan werkt de adoptie terug tot aan de geboorte. Dit kan problemen voorkomen als de geboortemoeder bijvoorbeeld bij de geboorte komt te overlijden, want ook dan, zo staat expliciet in de nieuwe regeling, kan de adoptie door de niet-biologische moeder door de rechter worden uitgesproken. Wordt het adoptieverzoek niet voor de geboorte maar wel binnen 6 maanden na de geboorte ingediend, dan werkt de adoptie, indien het verzoek wordt toegewezen, terug tot het moment van indiening van het verzoek.

Verder is er een onderscheid tussen bekende en onbekende donoren geïntroduceerd in de adoptiewetgeving. Indien gebruik is gemaakt van kunstmatige donorbevruchting als bedoeld in artikel 1, onder c, van de Wet Donorgegevens ${ }^{19}$ en ter bevestiging hiervan een verklaring van de Stichting Donorgegevens kan worden overlegd, wordt het adoptieverzoek in beginsel toegewezen. Wanneer ondanks het

\footnotetext{
${ }^{18}$ Wet van 24 oktober 2008 tot wijziging van Boek 1 van het Burgerlijk Wetboek in verband met verkorting van de adoptieprocedure en wijziging van de Wet opneming buitenlandse kinderen ter adoptie in verband met adoptie door echtgenoten van gelijk geslacht tezamen. Zie Staatsblad 2008, 425.

${ }^{19} \mathrm{Zie}$ art 1c Wet donorgegevens kunstmatige bevruchting. "Kunstmatige donorbevruchting: het beroepsof bedrijfsmatig verrichten van handelingen, gericht op het anders dan op natuurlijke wijze tot stand komen van een zwangerschap met gebruikmaking van: 1. zaad van een ander dan de echtgenoot, geregistreerde partner of andere levensgezel van de vrouw of 2. een eicel van een andere vrouw."
} 
kunnen overleggen van een degelijke verklaring de adoptie niet in het belang van het kind is of niet is voldaan aan de voorwaarden gesteld in artikel 1:228 BW wordt het verzoek afgewezen. Is gebruik gemaakt van een bekende donor en kan er geen verklaring van de Stichting Donorgegevens worden overlegd, dan zal de rechter tijdens de adoptieprocedure moeten toetsen of het kind nog iets te verwachten heeft van de ouder met wie de relatie door de adoptie wordt verbroken (zoals nu ook het geval is). ${ }^{20}$ In de context van adoptie wordt onder ouder ook verstaan de donor met family life. Als blijkt dat het kind nu en in de toekomst niets meer van de betreffende ouder kan verwachten, mag de niet-biologische moeder adopteren. Of de niet-biologische moeder door adoptie juridisch ouder wil worden is uiteindelijk haar keuze; is ze niet van zins het kind te adopteren, dan kan zij daar niet toe worden gedwongen, ondanks haar verantwoordelijkheid voor het ontstaan van het kind. ${ }^{21}$

In geval er overeenstemming is tussen moeders en bekende donor over de toedeling van het juridisch ouderschap van het kind, levert de huidige situatie niet veel problemen op. Er kan gekozen worden voor adoptie door de meemoeder of erkenning door de bekende donor. Hoe dan ook, het kind zal vaak twee juridische ouders hebben. ${ }^{22}$ Problemen ontstaan in geval van conflict over de toedeling van het ouderschap. Dit kan een conflict betreffen tussen de moeders en de bekende donor met family life, maar ook een conflict tussen de moeders onderling. Over conflicten tussen moeders en bekende donor is inmiddels veel geschreven en geprocedeerd. ${ }^{23}$ Duidelijk is geworden dat een donor met family life op grond van artikel 8 EVRM ontvankelijk kan zijn in een verzoek om vervangende toestemming tot erkenning. Daarnaast is ook duidelijk geworden dat de bekende donor met family life een rol van betekenis kan spelen in de adoptieprocedure van het kind door de mee-moeder. ${ }^{24}$ Een gevolg van het conflict tussen moeders en bekende donor kan zijn, dat het kind uiteindelijk maar één juridische ouder krijgt, terwijl er twee gegadigden zijn voor de tweede plek als juridische ouder.

Er is echter minder duidelijkheid over de gevolgen van conflicten tussen de moeder en de mee-moeder onderling over de toedeling van ouderschap. Dit kan enerzijds gaan om een conflict over het al dan niet toestemming geven tot erkenning aan de bekende donor en anderzijds om een conflict over het al dan niet verlenen van

\footnotetext{
${ }^{20}$ Zie artikel 1:227 lid 3 BW.

${ }^{21}$ De mannelijke levenspartner die met de verwekking van het kind heeft ingestemd kan hier wel toe worden gedwongen door de gerechtelijke vaststelling van zijn vaderschap. Zie artikel 1:207 BW.

${ }^{22}$ Wat ontbreekt in de huidige wetgeving is een goede regeling voor het waarborgen van het recht van het kind op afstammingsgegevens in geval de zwangerschap is ontstaan zonder tussen komst van een ziekenhuis.

${ }^{23}$ Forder, Erkenning door de vrouwelijke partner van de moeder: In welke mate heeft de biologische vader het recht het kind te erkennen, hoe werkt prenatale erkenning in deze context en welk recht heeft het kind van duo-moeders op afstammingsinformatie in het licht van het EVRM en IVRK? Februari 2009 (zie Kamerstukken II 2008-09, 30 551, nr 24). Zie bijvoorbeeld ook Vonk Lesbisch ouderschap en het afstammingsrecht: een, twee of toch drie ouders?, Tijdschrift voor familie- en jeugdrecht, 2009/105, Zie ook Van Raak-Kuiper, De donor en zijn vaderrol, een roze wolk?, Tijdschrift voor familie- en jeugdrecht, 2008/96.

${ }^{24}$ Zie bijvoorbeeld de noot van Vonk bij Hof Amsterdam 4 mei 2010, Jursiprudentie in Nederland 2010/599 voor een beknopt overzicht van deze zaak.
} 
toestemming tot adoptie door de geboortemoeder aan de mee-moeder. Een zaak waarin een conflict over toestemming tot adoptie speelde kwam recent voor de rechtbank Breda. ${ }^{25}$ De twee vrouwen waren voor de geboorte van het kind getrouwd en hadden gebruik gemaakt van het zaad van een bekende donor. De vrouwen hebben door de geboorte van het kind tijdens hun huwelijk gezamenlijk het gezag verkregen. Nadat de toen geldende verzorgingstermijn was verstreken, gingen de vrouwen nog niet tot adoptie over omdat zij graag de adoptie van dit kind en het tweede kind dat zij graag zouden krijgen tegelijkertijd wilden aanvragen. Maar voor er sprake is van een tweede kind, gaan de vrouwen uit elkaar en wordt een echtscheiding verzocht. De moeder van het kind heeft inmiddels een nieuwe partner en bij de scheiding wordt een omgangsregeling overeengekomen.

De mee-moeder wil het kind toch graag adopteren omdat zij meer en meer het gevoel heeft dat de moeder haar nieuwe partner als tweede moeder presenteert ten opzichte van het kind. Anderzijds wil de moeder graag dat haar nieuwe partner het kind adopteert. De mee-moeder dient een verzoek tot partner-adoptie in bij de rechtbank Breda. Ondanks het feit dat aan een aantal voorwaarden niet is voldaan, zoals de samenlevingseis en de instemming van de moeder van het kind, wijst de rechtbank Breda het verzoek toe omdat, zo stelt de rechtbank, de moeder misbruik heeft gemaakt van haar bevoegdheid haar instemming tot de adoptie al dan niet te verlenen. ${ }^{26}$ De moeder gaat vervolgens in hoger beroep en het Hof Den Bosch wijst het adoptieverzoek van de mee-moeder alsnog af. ${ }^{27}$ Leidend in deze beschikking is artikel 3 van het Verdrag voor de Rechten van het Kind, dat vereist dat bij een beslissing die een kind betreft de belangen van het kind één van de primaire overwegingen moet vormen. Het kind is inmiddels onder toezicht gesteld en uit nader onderzoek komt naar voren dat het kind in een loyaliteitsconflict verkeert tussen moeder en mee-moeder. Het Hof concludeert dat de adoptie voor het kind niets toevoegt, omdat het niet leidt tot de oplossing van de problemen waarin het kind verkeert. Derhalve acht het Hof de adoptie niet in het belang van het kind en vernietigt de beschikking van de rechtbank Breda. Let wel, de mee-moeder houdt het gezamenlijk gezag met de moeder. Dit betekent dat de nieuwe partner van de moeder het kind niet kan adopteren. Één van de vereisten van partneradoptie is immers dat de ouder of alleen of samen met de partner die wil adopteren het gezag heeft.

Het spiegelbeeld van deze situatie is te vinden in een andere recente beschikking van het Hof Den Bosch. ${ }^{28}$ Mevrouw A en mevrouw B hebben tijdens hun huwelijk met elkaar allebei een kind gekregen en hebben daarmee over de beide kinderen het gezamenlijk gezag verkregen. Zij hebben elkaars kinderen op hetzelfde moment geadopteerd. ${ }^{29}$ Het verzoek tot adoptie van kind $\mathrm{B}$ is voor de geboorte

\footnotetext{
${ }^{25}$ Zie rechtbank Breda 27 juli 2011, LJN BR2383

${ }^{26}$ Zie ook de noot van De Graaf bij de uitspraak van de rechtbank Breda van 27 juli 2011 in Jurisprudentie Personen- en Familierecht 2012/11.

${ }^{27}$ Zie hof Den Bosch 22 februari 2012, LJN BV6648.

${ }^{28}$ Zie hof Den Bosch 5 april 2012, LJN BW1034

${ }^{29}$ Zie rechtbank Den Bosch, 26 juli 2011 (niet gepubliceerd).
} 
ingediend en na de geboorte toegewezen. Ergens rondom de geboorte van kind B in de zomer van 2011 is de relatie tussen de vrouwen verbroken en op 17 februari 2012 is de echtscheiding ingeschreven in de registers. De vrouwen hebben een ouderschapsplan opgesteld met betrekking tot kind A, maar niet met betrekking tot kind B. Mevrouw A zegt geen band te hebben met kind B omdat ze het kind nooit heeft verzorgd. Omdat mevrouw A geen band heeft met kind B, verzoekt ze het Hof de door de rechtbank Den Bosch toegewezen adoptie te vernietigen op grond van wijziging van omstandigheden. Vrouw B is het met dit verzoek eens omdat zij graag de mogelijkheid wil openhouden voor adoptie van kind B door een mogelijke nieuwe partner. Het Hof stelt dat de wet geen mogelijkheid biedt om een adoptie te vernietigen op grond van gewijzigde omstandigheden, maar komt via een omweg toch op vernietiging uit. Het Hof stelt dat er door de rechtbank niet inhoudelijk is getoetst of adoptie in het belang van het kind is. Voor de verwekking van kind B was gebruik gemaakt van zaad van een onbekende donor, de inseminatie (er wordt in de beschikking over ivf gesproken) heeft in een kliniek plaatsgevonden en er kon dus een verklaring als genoemd in art. 1:227 lid 4 BW worden overlegd. De rechtbank heeft het verzoek tot adoptie zonder partijen te horen toegewezen, omdat aan alle criteria was voldaan. Het Hof stelt dat er dus nog niet is getoetst of de adoptie in het belang van het kind is, en doet dat alsnog aan de hand van de omstandigheden zoals die op dat moment zijn. Het Hof oordeelt dat er geen biologische of sociale band is tussen vrouw A en kind B en dat daarmee de adoptie niet in het belang van kind $B$ zou zijn. Het Hof vernietigt de beschikking van de rechtbank Den Bosch voor zover het de adoptie van kind B betreft. Het gezamenlijk gezag met betrekking tot kind B blijft ongewijzigd ook al stellen alle partijen en ook het Hof vast dat er geen biologische of sociale band bestaat tussen vrouw A en kind B.

De huidige regeling levert voor de betrokken partijen mogelijk problemen op wanneer het leven en/of de relatie zich anders ontwikkelen dan van te voren gedacht. Dat wordt uit deze twee zaken zonder meer duidelijk. In het eerste geval krijgt de meemoeder niet de juridische positie die ze wil hebben ten opzichte van het door haar gewenste kind en in het tweede geval krijgt het kind een andere juridische positie dan was voorzien. Er is in beide zaken geen sprake van gelijke behandeling van de moeder en de mee-moeder: de positie van de moeder is beduidend sterker dan die van de meemoeder. Daarnaast lijkt de bescherming van het gezin waarin het kind opgroeit heel letterlijk te worden genomen, als het kind niet meer bij de beide vrouwen opgroeit en er geen sprake is van een feitelijk gezin, lijkt de beschermingsgedachte in geval van conflict naar de achtergrond te worden gedwongen. Wat heeft het nieuwe wetsvoorstel voor consequenties in deze gevallen? Wat weten we eigenlijk over de ontwikkeling van kinderen in duo-moeder gezinnen? In de volgende secties wordt aandacht besteedt aan duo-moederschap vanuit ontwikkelingspsychologisch perspectief, waarbij met name aandacht is voor de aspecten die uit de juridische analyse naar voren zijn gekomen: het welzijn van het kind in het gezin waar het opgroeit, de gelijkstelling van de moeders en hun verhouding onderling en de relatie tussen het kind en de bekende 
donor. Een ander element dat nog niet heel helder naar voren is gekomen, maar wel gezien de maatschappelijke ontwikkelingen relevant is, betreft het meer-oudergezin.

\subsection{Belang en ontwikkeling van het kind}

Een belangrijk neveneffect van de eerdergenoemde 'lesbische babyboom' is dat er ook steeds meer onderzoek plaatsvindt naar hoe het de kinderen in deze gezinnen vergaat. Deze onderzoeken hebben zich in eerste instantie vooral gericht op kinderen in de leeftijd van 4 tot en met 12 jaar oud.

Kinderen groeien niet op in een vacuüm, maar hun opvoeding en ontwikkeling is onder andere ingebed in verschillende sociale en maatschappelijke contexten. ${ }^{30}$ Voor kinderen die opgroeien in een gezinssituatie met twee ouders van hetzelfde geslacht betekent dit dat zij opgroeien in een samenleving waarin heteroseksualiteit de norm is en zelfs sprake kan zijn van veel homonegativiteit. Hierdoor is de kans groot dat zij geconfronteerd worden met kinderen die hen pesten of vervelende vragen stellen omdat zij twee lesbische moeders hebben, en dit zou tot meer probleemgedragingen kunnen lijden. ${ }^{31}$ Echter, opmerkelijk is dat kinderen die opgroeien bij lesbische moeders aan de ene kant regelmatig stigmatisering mee maken, maar dat ze wanneer we ze vergelijken met leeftijdgenoten uit traditionele vader-moeder gezinnen, niet meer probleemgedragingen vertonen. Zo blijkt uit verschillende internationale onderzoeken dat kinderen die geboren zijn in een lesbische relatie vergelijkbare scores behaalden op probleemgedragingen met kinderen uit eenzelfde leeftijdsgroep die opgroeiden in een vader-moeder gezin. ${ }^{32}$ In de Engelstalige literatuur worden deze resultaten ook samengevat met de term 'no-difference consensus'. 33

Er zijn echter ook twee studies, waarin de bevindingen afwijken van deze 'nodifference consensus'. Vanfraussen ${ }^{34}$ en haar collega's vonden dat als het ging om

\footnotetext{
${ }^{30}$ Bronfenbrenner, Interacting systems in human development: Research paradigms: Present and future, in Niall \& Caspi (eds.), Persons in context: Developmental processes (pp. 25-49), New York: Cambridge University Press, 1988.

${ }^{31}$ Bos, Parenting in planned lesbian families. Amsterdam: Vossiuspers UvA, 2004.

${ }^{32}$ Bos, Van Balen \& Van den Boom, Child adjustment and parenting in planned lesbian-parent families, American Journal of Orthopsychiatry, 2007, 77, 38-48; Bos \& Van Balen, Children in planned lesbian families: stigmatisation, psychological adjustment and protective factors, Culture, Health, \& Sexualities, 2007, 10, 221-236; Brewaeys, Ponjaert-Kristoffersen, Van Steirteghm \& Devroey, Children from anonymous donors: An inquiry into homosexual and heterosexual parents' attitudes, Journal of Psychosomatic Obstetrics and Gynaecology, 1993, 14, 23-35; Flaks, Ficher, Masterpasqua \& Joseph, Lesbian choosing motherhood: A comparative study of lesbian and heterosexual parents and their children. Developmental Psychology, 1995, 31, 105-114; Patterson, Children of the lesbian baby boom: Behavioral adjustment, self-concepts, and sex-role identity, in Greene \& Herek (eds.), Psychological perspectives on lesbian and gay issues: Vol. 1. Lesbian and gay psychology: Theory, research, and clinical applications (pp. 156-175), Thousand Oaks, CA: Sage, 1994; Steckel, Psychosocial development of children of lesbian mothers. Gay and lesbian parents, in Bozett (ed.), Homosexuality and family relations (pp. 23-36), New York: Harrington Park, 1987; Golombok, Perry, Burston, Murray, Mooney-Somers, Stevens, \& Golding, Children with lesbian parents: A community study, Developmental Psychology, 2003, 39, 20-33.

${ }^{33}$ Stacey \& Biblarz, (How) does the sexual orientation of parents matter? American Sociological Review, 2001, 66, 159-183.

${ }^{34}$ Vanfraussen, Pontjaert-Kristoffersen \& Brewaeys, Family functioning in lesbian families created by donor insemination. American Journal of Orthopsychiatry, 2003, 73, 78-90.
} 
probleemgedragingen van de kinderen gerapporteerd door moeders zelf, er geen verschillen met kinderen uit heteroseksuele vader-moeder gezinnen zijn. Dit vonden zij ook toen ze de kinderen zelf allerlei vragenlijsten lieten invullen. Echter toen zij ook de docenten van de kinderen vroegen om een probleemgedragingen lijst in te vullen voor dezelfde groep vonden zij meer aandachtsproblemen bij de kinderen met twee moeders. Een verklaring zou kunnen zijn dat docenten de kinderen in een heel andere context zien dan bijvoorbeeld de moeders en daarmee misschien ook wel anders waarnemen bij de kinderen.

Ook de resultaten uit het US National Longitudinal Lesbian Family Study (US $N L L F S$ ) zijn (nu in positieve zin voor de kinderen uit de lesbische gezinnen) niet in lijn met de 'no-difference consensus'. In dit longitudinale onderzoek waarin moeders en hun kroost al zo'n 17 jaar gevolgd worden (met meetmomenten toen de moeders zwanger waren en toen de kinderen 2, 4, 10 en 17 jaar oud waren) is de ontwikkeling van de eerste generatie kinderen, opgroeiend in een lesbisch gezin, gevolgd. Op het moment dat de kinderen 10 jaar oud waren was de gemiddelde score van de meisjes op externaliserende probleemgedragingen lager dan die van 10 -jarige meisjes opgroeiend in een vader-moeder gezin uit een vergelijkingsgroep. ${ }^{35}$

In tegenstelling tot de inmiddels grote hoeveelheid studies die is uitgevoerd onder kinderen met twee lesbische moeders, ${ }^{36}$ is er nog maar een klein aantal studies gedaan naar adolescenten die in twee-moeder gezinnen opgroeien. ${ }^{37}$ Uit deze recente publicaties blijkt dat, in vergelijking met adolescenten bestaande uit een controlegroep met tieners van eenzelfde leeftijd en die op allerlei sociaal-demografische aspecten ook overeen kwamen met de twee-moeder gezinnen, adolescenten uit 'planned lesbian families' geen verschillen laten zien in bijvoorbeeld hun psychosociale ontwikkeling, of zelfs op sommige aspecten een positiever beeld laten zien. Uit het US NLLFS blijkt verder dat op 17-jarige leeftijd geen enkele adolescent uit dit onderzoek zegt fysiek of seksueel misbruikt te zijn door een ouder of andere verzorger, terwijl onder Amerikaanse jongeren dit percentage veel hoger ligt voor zowel fysiek (26\%) als seksueel $(8.3 \%)$ misbruik. ${ }^{38}$ Uit dit maar ook uit andere onderzoeken die hierboven zijn opgenoemd is dan ook te concluderen dat het opgroeien in een gezin bestaande uit

\footnotetext{
${ }^{35}$ Gartrell, Deck, Rodas, Peyser \& Banks, The National Lesbian Family Study: 4. Interviews with the 10-year-old children, American Journal of Orthopsychiatry, 2005, 75, 518-524.

${ }^{36}$ Bos \& van Balen, Children of the new reproductive technologies: social and genetic parenthood, Patient Education and Counseling, 2010, 81, 429-435.

${ }^{37}$ Bos \& Gartrell, Adolescents of the U.S. National LongitudinalLesbian Family Study: Can family characteristics counteract the negative effects of stigmatization?, Family Process, 2010, 49, 559-572; Bos \& Gartrell, Adolescents of the U.S. National Longitudinal Lesbian Family Study: The impact of having a known or an unknown donor on the stability of psychological adjustment, Human Reproduction, 2010 (first published online December 17, 2010); Gartrell \& Bos, The US National Longitudinal Lesbian Family Study: Psychological Adjustment of the 17-year-old Adolescents, Pediatrics, 2010, 126, 1-9; Golombok \& Badger, Children raised in mother-headed families from infancy: a follow-up of children of lesbian and heterosexual mothers, at early adulthood, Human Reproduction, 2010, 25, 150-157.

${ }^{38}$ Gartrell, Bos \& Goldberg, Adolescents of the U.S. National Longitudinal Lesbian Family Study: Sexual orientation, sexual behavior, sexual risk exposure, Archives of Sexual Behavior (online first since 6 November 2010).
} 
twee ouders van hetzelfde geslacht dus niet per definitie iets is wat gezien kan worden als een risicofactor.

Van het begin af aan is er een ander aspect in de ontwikkeling van kinderen dat telkens weer naar voren komt in de argumenten die tegenstanders van lesbisch ouderschap aanhalen, namelijk het argument dat deze kinderen een atypische gender identiteit zouden ontwikkelen. De empirische onderzoeksresultaten zijn hier minder eenduidig over: Zo vonden MacCallum en Golombok ${ }^{39}$ dat jongens in lesbische gezinnen meer vrouwelijke persoonlijkheidskenmerken rapporteerden dan jongens in een vader-moeder gezin. Echter, er zijn ook tal van onderzoeken waarin deze verschillen niet gevonden zijn. ${ }^{40}$ Bos en Sandfort ${ }^{41}$ zagen in hun onderzoek wel dat kinderen in lesbische gezinnen in vergelijking met hun leeftijdgenoten in heteroseksuele vader-moeder gezinnen op relatief jonge leeftijd (tussen 8 en 12 jaar oud) vragen stellen bij de vanzelfsprekendheid van een heteroseksuele relatie. Overigens zegt dit uiteraard niets over de eigen seksuele voorkeur van de kinderen. Deze seksuele voorkeur is wel bekeken in het eerder genoemde onderzoek van de NLLFS: op de leeftijd van 17 jaar zegt slechts een klein percentage $(2.8 \%)$ van de NLLFS-adolescenten dat zij voornamelijk tot exclusief een homoseksuele identiteit hebben. Dit percentage is min of meer gelijk aan het percentage adolescenten in (grote) populatie onderzoeken onder Amerikaanse jongeren. ${ }^{42}$

\subsection{Verhouding tussen de moeders onderling}

Lesbische vrouwen die in een relatie kinderen opvoeden hebben altijd te maken met het gegeven dat één van de twee het kind gebaard heeft, en dat vanuit de maatschappelijke en de juridische norm diegene die gebaard heeft als de 'echte' moeder gezien wordt. ${ }^{43}$ Onderzoek heeft trouwens laten zien dat het vaak zeer praktische redenen zijn waarom juist de ene moeder en niet de andere moeder zwanger was en het kind of de kinderen gebaard heeft. Veel stellen zeggen bijvoorbeeld dat het voor de ene moeder (de biologische moeder) makkelijker te combineren was met haar werk dan voor de andere moeder (de duo-moeder ook wel sociale-moeder genoemd). ${ }^{44}$

\footnotetext{
${ }^{39}$ MacCallum \& Golombok, Children raised in fatherless families from infancy: A follow-up of children of lesbian and single heterosexual mothers at early adolescence, Journal of Child Psychology and Psychiatry, 2004, 45, 1407-1419.

${ }^{40}$ Bos \& Sandfort, Children's gender identity in lesbian and heterosexual two-parent families, Sex Roles, 2010, 62, 114-126; Brewaeys, Ponjaert, Van Hall \& Golombok, Donor insemination: child development \& family functioning in lesbian mother families with 4 to 8 year old children, Human Reproduction, 1997, 12, 1349-1359.

${ }^{41}$ Bos \& Sandfort, Children's gender identity in lesbian and heterosexual two-parent families, Sex Roles, 2010, 62, 114-126.

${ }^{42}$ Gartrell, Bos, \& Goldberg, Adolescents of the U.S. National Longitudinal Lesbian Family Study: Sexual orientation, sexual behavior, sexual risk exposure, Archives of Sexual Behavior (online first since 6 November 2010).

${ }^{43}$ Rothuizen, Lesbisch ouderschap, in De Bruin \& Balkema (eds.), Liever vrouwen. Theorie en praktijk van de lesbisch-specifieke hulpverlening (pp.119-136), Amsterdam: Schorer Boeken, 2001.

${ }^{44}$ Chabot \& Ames, "It wasn't let's get pregnant and go do it": Decision-making in lesbian couples planning motherhood via donor insemination, Family Relations, 2004, 53, 348-356; Goldberg \& Sayer,
} 
Sommige auteurs zeggen dat vrouwen het verschil in biologisch en duomoederschap zelf ook zo kunnen ervaren. En als gevolg hiervan zouden ze ook van elkaar kunnen verschillen in hoe zij het moederschap invullen en/of in de wijze waarop zij met hun kind(eren) omgaan. ${ }^{45}$

Dit vraagstuk naar verschillen in beleving van het ouderschap en opvoedingsgedrag tussen beide moeders is slechts in een beperkt aantal studies bekeken. Goldberg en haar collega's ${ }^{46}$ hebben bijvoorbeeld aan vrouwen zelf gevraagd of zij bij hun kinderen een voorkeur waarnamen voor de ene (biologische) dan wel andere (niet biologische) moeder. In dit onderzoek gaven vrouwen zelf aan dat in de eerste levensjaren er een voorkeur van het kind was voor de biologische moeder. Ook signaleerden de moeders in dit onderzoek dat deze voorkeur voor de biologische moeder in de eerste levensperiode van het kind na verloop van tijd verdween en het kind even veel naar beide moeders toe ging trekken. Als verklaring voor het feit dat in de beginperiode kinderen naar de biologische moeder trekken gaven de vrouwen op de ervaring van de zwangerschap en het geven van borstvoeding in de eerste maanden. De meeste moeders zagen dit beiden als een vanzelfsprekendheid. Over het algemeen hebben sociale-moeders daar ook geen problemen mee. Toch is er wel een aantal moeders in de NLLFS dat aangeeft dat zij het als een gemis ervaren dat zij niet door het geven van borstvoeding een vanzelfsprekende band met het kind hebben kunnen opbouwen. $^{47}$

In vergelijking met vader-moeder gezinnen is de verdeling van de taken in het gezin (huishouden, zorg voor de kinderen en buitenshuis werken) tussen beide ouders in de twee-moeder gezinnen veel meer gebaseerd op een gelijke verdeling: Beide moeders besteden evenveel tijd aan het huishouden en het buitenshuis werken. ${ }^{48}$ Alhoewel sommige onderzoeken ook aantonen dat de biologische moeder meer uren per week besteedt aan de zorg voor de kinderen dan de sociale moeder. ${ }^{49}$ Maar ook dan omschrijven beide moeders zich als 'primaire' verzorger of opvoeder, ${ }^{50}$ en zijn er geen verschillen gevonden tussen beide moeders met betrekking tot hoe tevreden zij zijn over hun partner als mede- opvoeder. ${ }^{51}$

Lesbian couples' relationship quality across the transition to parenthood, Journal of Marriage and Family, 2006, 68, 87-100.

${ }^{45}$ Rothuizen, Lesbisch ouderschap, in De Bruin \& Balkema (eds.), Liever vrouwen. Theorie en praktijk van de lesbisch-specifieke hulpverlening (pp.119-136), Amsterdam: Schorer Boeken, 2001.

${ }^{46}$ Goldberg, Downing \& Sauck, Perceptions of children's parental preferences in lesbian two-mother households, Journal of Marriage and Family, 2008, 70, 419-434

${ }^{47}$ Gartrell, Banks, Hamilton, Reed, Bishop,\& Rodas, The National Lesbian Family Study: 2. Interviews with mothers of toddlers, American Journal of Orthopsychiatry, 1999, 69, 362-369.

${ }^{48}$ Bos, Van Balen \& Van den Boom, Child adjustment and parenting in planned lesbian-parent families, American Journal of Orthopsychiatry, 2007, 77, 38-48.

${ }^{49}$ Bos, Van Balen \& Van den Boom, Child adjustment and parenting in planned lesbian-parent families, American Journal of Orthopsychiatry, 2007, 77, 38-48.

${ }^{50}$ Goldberg \& Perry-Jenkins, The division of labor and perceptions of parental roles: Lesbian couples across the transition to parenthood, Journal of Social and Personal Relationships, 2007, 24, 297-318

${ }^{51}$ Bos, Van Balen \& Van den Boom, Child adjustment and parenting in planned lesbian-parent families, American Journal of Orthopsychiatry, 2007, 77, 38-48. 
In het US NLLFS-onderzoek werd - toen de kinderen twee jaar oud waren gevonden dat wanneer de moeders conflicten hadden over de opvoeding van hun kind het dan ging over het feit dat beiden graag tijd met het kind wilden doorbrengen; in plaats van dat de ene ouder vindt dat de andere ouder te weinig tijd met het kind doorbrengt. ${ }^{52}$ Soms leidt dit tot competitie tussen de beide moeders. De US NLLFS heeft ook laten zien dat deze gevoelens van competitie en jaloezie met het ouder worden van de kinderen ook verdwijnen. ${ }^{53}$ Wat daarvoor in de plaats komt is dat vrouwen het gevoel hebben dat het ouderschap zo veel tijd kost dat zij niet meer toe komen aan elkaar. ${ }^{54}$

\subsection{De verhouding tussen het kind en de donor}

Kinderen van lesbische moeders worden of verwekt door kunstmatige inseminatie of door zelfinseminatie met sperma van een donor. Bij zelfinseminatie kan de donor een vriend of kennis van de moeders zijn en deze kan in meer of mindere mate betrokken zijn bij de opvoeding (zie ook de paragraaf over meer-ouder gezinnen). Lesbische vrouwen die voor zelfinseminatie kiezen, doen dit vaak omdat zij vinden dat een kind het recht heeft om te weten van wie hij of zij genetisch afstamt en dat hij/zij al op jonge leeftijd een band moet kunnen opbouwen met deze donor. Ook wordt door vrouwen genoemd dat zij bang zijn dat hun kind vooral in de adolescentie psychosociale problemen en identiteitsproblemen zal ondervinden vanwege het niet weten wie hun biologische vader is. ${ }^{55}$

Bij kunstmatige inseminatie met sperma in een ziekenhuis of kliniek is het in verschillende landen (nog steeds) mogelijk om te kiezen tussen zaad van een anonieme of een niet-anonieme donor. In veel landen, zoals bijvoorbeeld in Nederland, was dit tot een aantal jaren geleden ook mogelijk maar inmiddels is de wetgeving veranderd en is het alleen maar mogelijk om een kind te verwekken met zaad van een niet-anonieme donor. Dit wil zeggen dat als het kind meerderjarig is de gegevens van de donor op

\footnotetext{
${ }^{52}$ Gartrell, Banks, Hamilton, Reed, Bishop \& Rodas, The National Lesbian Family Study: 2. Interviews with mothers of toddlers, American Journal of Orthopsychiatry, 1999, 69, 362-369; Gartrell, Peyser, \& Bos, (in press), Planned lesbian families: A review of the U.S. National Longitudinal Lesbian Family Study, in Brodizinsky, Pertman, Kunz (eds.), Lesbian and gay adoption. A new American reality, Oxford: Oxford University Press, 2012.

${ }^{53}$ Gartrell, Banks, Reed, Hamilton, Rodas, \& Deck, The National Lesbian Family Study: 3. Interviews with mothers of five-year-olds, American Journal of Orthopsychiatry, 2000, 70, 542-548; Gartrell, Peyser, \& Bos, (in press), Planned lesbian families: A review of the U.S. National Longitudinal Lesbian Family Study, in Brodizinsky, Pertman, Kunz (eds.), Lesbian and gay adoption. A new American reality, Oxford: Oxford University Press. 2012.

${ }^{54}$ Gartrell, Deck., Rodas, Peyser \& Banks, The National Lesbian Family Study: 4. Interviews with the 10-year-old children, American Journal of Orthopsychiatry, 2005, 75, 518-524.

${ }^{55}$ Baetens \& Brewaeys, Lesbian couples requesting donor insemination: an update of the knowledge with regard to lesbian mother families, Human Reproduction Update, 2001, 7, 512-519; Baetens, Pontjaert-Kristoffersen, Van Steirteghem, Devroey, Counseling lesbian couples in creating a family by artificial insemination by donor, Human Reproduction, 1996, 11, 79; Almack,

Seeking sperm: accounts of lesbian couples' reproductive decision-making and understandings of the needs of the child. International Journal of Law Policy and the Family 2006, 20,1-22; Goldberg, Lesbian and gay parents and their children. Research on the Family Life Cycle, Washington DC, USA: American Psychological Association, 2010.
} 
verzoek van het kind aan hem of haar bekend gemaakt kunnen worden. In Europa is de wetgeving echter niet eenduidig inzake de mogelijkheid voor een anonieme of een niet-anonieme donor. Zo is in België bijvoorbeeld alleen spermadonatie van een onbekende donor mogelijk. ${ }^{56}$

Vanfraussen et al. ${ }^{57}$ vroeg aan de kinderen in haar onderzoek (gemiddelde leeftijd 10 jaar oud) of zij iets wilden weten van hun donor en wat zij dan wilden weten. Opvallend was dat ongeveer de helft van al de kinderen met twee moeders aangaf dat zij graag meer informatie wilden hebben over de donor en dat zij met name geïnteresseerd waren in hoe hij eruit ziet en wat zijn persoonlijkheid is. Zij hadden echter niet de intentie om een familieband met hem op te bouwen. Soortgelijke resultaten vond Scheib et al. ${ }^{58}$ onder adolescenten (tussen 12 en 17 jaar oud) in de VS: Jongeren waren met name nieuwsgierig naar iemands karakter en uiterlijk.

In het US NLLFS gaven de moeders, die kozen voor een onbekende donor, al heel vroeg (toen zij zwanger waren of bezig waren met inseminatie) aan dat zij bezorgd waren over wat hun donorkeuze in de toekomst zou betekenen voor het welbevinden van hun kinderen. ${ }^{59}$ Op het moment dat de kinderen 17 jaar oud zijn is hiervan nog weinig terug te zien: Er zijn geen verschillen in het psychosociaal welbevinden van de kinderen die verwekt zijn door zelfinseminatie met sperma van een bekende uit de omgeving van de moeders en de kinderen die verwekt zijn in een ziekenhuis of kliniek met sperma van een bekende of onbekende donor. Bijna al de 17jarigen uit de NLLFS die de mogelijkheid hebben om straks als zij 18 jaar oud zijn informatie te krijgen over hun donor (en dat ging om 18 kinderen) gaven aan ook van deze mogelijkheid gebruik te willen maken. ${ }^{60}$

\subsection{Meer-ouder gezinnen}

Een meer-ouderschap situatie heeft zijn voor- en nadelen. Het kan een voordeel zijn dat de stress en drukte die gepaard kan gaan met het opvoeden van kinderen door meerdere volwassenen gedeeld worden. Het kan echter ook weer stressvol zijn om met meer dan twee volwassenen de opvoeding en opvoedingsstijlen op elkaar af te stemmen. Een ander nadeel is dat het voor het kind onrustig en/of verwarrend kan zijn om nu in het ene en dan weer in het andere huishouden te verblijven. In deze zin zijn

\footnotetext{
${ }^{56}$ Vanfraussen, Ponjaert- Kristoffersen \& Brewaeys, Family functioning in lesbian families created by donor insemination, American Journal of Orthopsychiatry, 2003, 73, 78-90.

${ }^{57}$ Vanfraussen, Ponjaert- Kristoffersen \& Brewaeys, What does it mean for youngster to grow up in a lesbian family created by means of donor insemination?, Journal of Reproductive and Infant Psychology, 2002, 20, 237-252; Vanfraussen, Ponjaert- Kristoffersen \& Brewaeys, Why do children want to know more about the donor? The experience of youngsters raised in lesbian families, Journal of Psychosomatic Obstetrics and Gynaecology, 2003, 24, 31-38.

${ }^{58}$ Scheib, Riordan, \& Rubin, (2005). Adolescents with open-identity sperm donors: reports from 12-17 year olds. Human Reproduction, 2005, 20, 239-252.

${ }_{59}$ Gartrell, Hamilton, Banks, Mosbacher, Reed, Sparks, \& Bishop, The national lesbian family study: 1. Interviews with prospective mothers, American Journal of Orthopsychiatry, 1996, 66, 272-281.

${ }^{60}$ Bos \& Gartrell, Adolescents of the U.S. National Longitudinal Lesbian Family Study: The impact of having a known or an unknown donor on the stability of psychological adjustment, Human Reproduction, (first published online December 17, 2010).
} 
deze gezinnen min of meer te vergelijken met heteroseksuele ouders die na een scheiding voor co-ouderschap kiezen, maar waar één of beide ouders een nieuwe partner heeft die ook betrokken is bij de opvoeding door zijn of haar partner.

Vermoedelijk kiezen steeds meer lesbische vrouwen in Nederland voor zo'n soort co-ouderschap constructie omdat het aantal spermadonoren, dat zich bij ziekenhuizen en klinieken aanmeldt, is teruggelopen. Sinds 1 januari 2006 is het in Nederland namelijk niet meer mogelijk om een anonieme donor te zijn, ${ }^{61}$ wat lange wachtlijsten tot gevolg heeft. Veel lesbische vrouwen met een kinderwens ontlopen deze lange wachtlijsten door naar een spermadonor te zoeken in hun directe omgeving. ${ }^{62}$ Ondanks de snelle opkomst van het 'meer-ouderschap' biedt de verandering in de wetgeving voor deze gezinnen nog geen mogelijkheid om dit juridisch vast te leggen. ${ }^{63}$

Er is over deze vorm van meer-ouderschap waarin een mannenstel met een vrouwenstel kinderen krijgt en samen deze kinderen opvoeden, nog maar weinig bekend. In 2009 is er aan de Universiteit van Amsterdam een eerste studie gedaan naar deze zeer nieuwe gezinsvorming. ${ }^{64}$ De 37 homoseksuele mannen die meededen aan dit onderzoek waren allemaal vader geworden door sperma te doneren aan een lesbisch stel met wie ze in co-ouderschap hun kind(eren) opvoeden. Gemiddeld waren de kinderen (die tussen de 4 en 12 jaar oud waren) 11,5 dag per maand daadwerkelijk in het huishouden van de vaders aanwezig. De vaders uit deze meer-oudergezinnen zijn in dit onderzoek vergeleken met vaders uit heteroseksuele vader-moeder gezinnen. Het belangrijkste resultaat van deze studie is dat er geen significante verschillen gevonden zijn tussen de vaders in deze twee typen gezinnen met betrekking tot emotionele betrokkenheid en ouderlijke bezorgdheid (vader-kind relatie), ouderlijke last (als onderdeel van ouderlijke stress), of het welzijn van het kind. Homoseksuele-vaders voelden zich echter wel minder competent in hun opvoedersrol dan heteroseksuelevaders. ${ }^{65}$ Het zou kunnen zijn dat de homoseksuele-vaders ook hogere eisen aan zichzelf stellen in wat volgens hen een 'goede vader' is. Hier zijn echter nog geen gegevens over bekend. Een andere mogelijke verklaring voor het gevonden verschil in het zich competent voelen zou de pionierspositie kunnen zijn van deze eerste generatie homoseksuele mannen die vader worden na hun coming-out. De eerste generatie IVFouders rapporteerden ook vaker dan ouders die op natuurlijke wijze kinderen hadden

\footnotetext{
${ }^{61}$ Bos \& Hakvoort, Child adjustment and parenting in planned lesbian families with known and as-yet unknown donors, Journal of Psychosomatic Obstetrics \& Gynecology, 2007, 28, 121-129.

${ }^{62}$ Bos \& Hakvoort, Child adjustment and parenting in planned lesbian families with known and as-yet unknown donors, Journal of Psychosomatic Obstetrics \& Gynecology, 2007, 28, 121-129.

${ }^{63}$ Ministerie van Justitie, Sneller ouderschap voor duomoeder. Geraadpleegd op december 2009 via: http://www.justitie.nl/actueel/nieuwsberichten/archief-2009/91215sneller-ouderschap-voorduomoeder.aspx, 2009.

${ }^{64}$ Bos, Planned gay father families in kinship arrangements, Australian and New Zealand Journal of Family Therapy, 2010, 31, 356-371

${ }^{65}$ Bos, Planned gay father families in kinship arrangements, Australian and New Zealand Journal of Family Therapy, 2010, 31, 356-371
} 
gekregen dat zij de opvoeding niet aankonden. ${ }^{66}$ Opvallend was daarbij dat dit verschil niet terug te vinden was in observatiestudies en alleen gebaseerd was op vragenlijstonderzoek. ${ }^{67}$ In latere studies onder de tweede of derde generatie IVFouders waarbij gegevens werden verzameld door middel van vragenlijsten (al dan niet in combinatie met observaties) is dit verschil niet meer gesignaleerd. ${ }^{68}$

Een ander interessant resultaat uit deze eerste studie naar meer-ouder gezinnen bestaande uit een homomannen stel en een lesbische vrouwen stel is dat de homoseksuele vaders relatief weinig opvoedingsconflicten rapporteren met de moeders van de kinderen. Het kan zijn dat dit een weerspiegeling is van een goede verstandhouding met de moeders. Een verklaring hiervoor kan zijn dat al de betrokken ouders in deze vorm van meer-ouderschap gezinnen vanaf het begin hier heel bewust voor hebben gekozen. Dit in tegenstelling tot bijvoorbeeld 'patchwork gezinnen' die na een scheiding ontstaan zijn en waarin het kind niet vanaf het begin met meerdere volwassen opvoeders te maken heeft. Daarbij moet er wel rekening mee gehouden worden dat het in de onderzoeksgroep niet om hele kleine kinderen (jonger dan 4 jaar) ging waar al de betrokken ouders wellicht nog in een soort van strijd betrokken zijn om een emotionele band met het kind op te bouwen.

\section{Lesbisch moederschap in het afstammingsrecht}

Uit het hierboven uiteengezette onderzoek naar de ontwikkeling van kinderen in een gezin met twee moeders blijkt dat hun ontwikkeling niet wezenlijk verschilt van de ontwikkeling van kinderen in een gezin met een moeder en een vader. Vanuit ontwikkelingspsychologisch perspectief lijken er geen argumenten te zijn tegen het wettelijk verankeren van duo-moederschap in het afstammingsrecht, zoals in het op 4 oktober 2011 in de Tweede Kamer ingediende wetsvoorstel wordt beoogd. ${ }^{69}$ De voorgestelde regeling houdt in dat de mee-moeder het kind van haar partner niet langer hoeft te adopteren om juridisch ouder te worden. Zij zal dit dan afhankelijk van een aantal factoren of van rechtswege kunnen worden of via erkenning. Factoren die daarbij een rol spelen zijn enerzijds de vraag of de vrouwen met elkaar zijn getrouwd en anderzijds de vraag of zij gebruik hebben gemaakt van een onbekende donor. Uit de combinatie van deze twee factoren zoals die in het wetsvoorstel zijn vormgegeven, kunnen 4 verschillende soorten duo-moedergezinnen worden onderscheiden. Namelijk: 1. het gehuwde duo-moedergezin waar gebruik is gemaakt van een onbekende donor (de niet-biologische moeder is in dat geval automatisch juridisch moeder ingevolge art.

\footnotetext{
${ }^{66}$ Bos \& van Balen, Children of the new reproductive technologies: social and genetic parenthood, Patient Education and Counseling, 2010, 81, 429-435.

${ }^{67}$ Colpin, Parenting and psychosocial development of IVF children: Review of the research literature, Developmental Review, 2002, 22, 644- 673; Van Balen, F. (1998). Development of IVF children. Developmental Review, 18, 17, 30-46.

${ }^{68}$ Gibson, Development, behaviour and temperament: A prospective study of infants conceived through in-vitro fertilization, Human Reproduction, 1998, 13, 1727-1732; McMahon, Psychosocial adjustment and the quality of the mother-child relationship at four months postpartum after conception by in vitro fertilization, Fertility and Sterility, 1997, 68, 492-500.

${ }^{69}$ Zie Kamerstukken II 2011-12, 33032 nrs. 1 tot en met 3.
} 
1:198 lid 1 onder b BW (nieuw)); 2. het ongehuwde duo-moedergezin dat gebruik heeft gemaakt van een onbekende donor; 3 . het duo-moedergezin dat gebruik heeft gemaakt van een bekende donor zonder ouderschapsintenties; en 4 . het duomoedergezin dat gebruik heeft gemaakt van een bekende donor met ouderschapsintenties (family life).

In geval 1 komt het ouderschap van de niet-biologische moeder van rechtswege tot stand mits er een verklaring van de Stichting Donorgegevens wordt overgelegd bij de geboorteaangifte. ${ }^{70}$ In gevallen 2 en 3 komt het ouderschap van de niet-biologische moeder niet van rechtswege tot stand, ondanks het feit dat er geen andere partij aanspraak maakt op het ouderschap dan de niet-biologische moeder. In geval 2 komt dit omdat de donor onbekend is en in geval $\mathbf{3}$ omdat de donor heeft aangegeven geen ouderschapsintenties te hebben. In geval 4 komt het ouderschap niet van rechtswege tot stand omdat er een bekende donor is die ouderschapsintenties heeft (family life) met wiens 'rechten' rekening gehouden dient te worden bij de regeling van het ouderschap van de niet-biologische moeder. ${ }^{71}$ In de gevallen 2, 3 en 4 waar het ouderschap van de niet-biologische moeder niet van rechtswege tot stand komt, wordt het voor de meemoeder mogelijk het kind van haar partner te erkennen. Zij heeft daarvoor wel toestemming van de moeder nodig. ${ }^{72}$ De positie van de donor met ouderschapsintenties wordt versterkt doordat hij vervangende toestemming tot erkenning aan de rechter kan verzoeken. $^{73}$

De niet-biologische moeder zelf krijgt niet de mogelijkheid om aan de rechter vervangende toestemming tot erkenning te vragen. Wanneer de geboortemoeder weigert toestemming te geven, bijvoorbeeld doordat er tijdens de zwangerschap een conflict tussen beide vrouwen is ontstaan, staat de niet-biologische moeder met lege handen. Het moederschap van de meemoeder kan echter wel gerechtelijk worden vastgesteld op verzoek van geboortemoeder of het kind op grond van het feit dat zij als levensgezel van de moeder heeft ingestemd met een daad die de verwekking van het kind tot gevolg kan hebben gehad (deze regeling geldt thans ook voor de mannelijke instemmende levensgezel). ${ }^{74}$ Het vaderschap van de bekende donor met ouderschapsintenties kan daarentegen niet gerechtelijk worden vastgesteld (ook niet op verzoek van het kind).

\footnotetext{
${ }^{70}$ Zie artikel 1:198 onder b BW (nieuw). Zie over de rol van de ambtenaar Forder, De ambtenaar van de Burgelijke Stand als hoeder van de kinderrechten, Burgerzaken en Recht, 2010, 10, 342-345.

${ }^{71}$ Dit is uiteindelijk de situatie waarnaar de Minister naar aanleiding van het rapport van de Commissie Kalsbeek nader onderzoek heeft gevraagd. Zie over de eerdere genoemde rapporten: Vonk, Duomoeders en hun kinderen, in Boele-Woelki (eds.) Actuele ontwikkelingen in het familierecht UCERF reeks 2, Nijmegen: Ars Aequi, 2008 (digitaal beschikbaar via http://igiturarchive.library.uu.nl/search/search.php), en Vonk, Lesbisch ouderschap en het afstammingsrecht: een, twee of toch drie ouders?, Tijdschrift voor familie- en jeugdrecht 2009/105. Zie ook Van Raak-Kuiper, De donor en zijn vaderrol, een roze wolk? Tijdschrift voor familie- en jeugdrecht, 2008/96.

${ }^{72}$ Zie de artikelen 1:198 onder c BW en 1:204 lid $1 \mathrm{BW}$ (nieuw).

${ }^{73}$ Zie artikel 1:204 lid 3 BW (nieuw). Hierbij wordt ook de rechtspraak van de Hoge Raad meegenomen omtrent de vernietiging van erkenning gedaan door een derde waar de moeder misbruik heeft gemaakt van haar bevoegdheid om toestemming aan de derde te geven (Hoge Raad 12 november 2004, NJ 2005, 248).

${ }^{74}$ Zie artikel 1:207 BW (nieuw).
} 
De door de wetgever gemaakte keuze met betrekking tot de posities van de mee-moeder en de donor in het afstammingsrecht heeft een aantal consequenties. Ten eerste betekent dit dat in die gevallen waar het ouderschap van de ander met toestemming van de moeder tot stand komt, de moeder mag kiezen wie de ouder wordt van haar kind. Tegen deze keuze kan alleen de bekende donor met ouderschapsintenties in zeer specifieke omstandigheden in het geweer komen. Ten tweede betekent dit dat in die gevallen waar het ouderschap tegen de wil van de moeder of het kind tot stand kan komen, namelijk via vervangende toestemming tot erkenning, alleen de bekende donor met family life (de biologische vader) ontvankelijk is. Ten derde houdt dit in dat waar moeder of kind verzoekt het ouderschap gerechtelijk te laten vaststellen, ze dat alleen kan doen ten opzichte van de niet-biologische moeder en niet ten opzicht van de bekende donor met ouderschapsintenties. De vraag die met name deze laatste mogelijkheid oproept is welke invloed dit recht om ouder te worden heeft op de plichten die een niet-juridische biologische ouder heeft, zoals de plicht tot het betalen van kinderalimentatie in geval het kind alleen een moeder heeft ${ }^{75}$ en de al eerder genoemde vaststelling van het vaderschap. Kortom, is het mogelijk om de bekende donor met family life een rechtsingang te geven om juridisch ouder te worden, zonder dat de andere partijen een rechtsingang krijgen om hem bijvoorbeeld kinderalimentatie te laten betalen of om zijn vaderschap gerechtelijk te laten vaststellen? Dit zal met name een rol spelen in die gevallen waar een vrouw zonder partner met behulp van een bekende donor een kind heeft gekregen. ${ }^{76}$

In al die gevallen waar de partijen geen conflict hebben over wie de juridische ouders van het kind zullen zijn, lijkt het wetsvoorstel genoeg oplossingen te bieden. Door onderscheid te maken bij huwelijk tussen een bekende en een onbekende donor, blijft de mogelijkheid voor de betrokkenen in stand om zelf een keuze te maken wie welke juridische band krijg met het kind. Waar geen conflict is, zou ook kunnen worden overwogen de verklaring waarin de bekende donor stelt geen ouderschapsintenties te hebben, gelijk te stellen aan de verklaring van de Stichting Donorgegevens, zodat ook dan het moederschap van de gehuwde mee-moeder automatisch bij de geboorte aangifte tot stand komt. Maar wat gebeurt er in geval van conflict? Wanneer de moeders een conflict hebben met een bekende donor met family life over erkenning is met name de positie van de bekende donor versterkt. Het zal in de praktijk moeten blijken naar welk ouderschap in zo'n geval de voorkeur uitgaat, dat van de mee-moeder of dat van de bekende donor met family life. De wetgever heeft hier vooralsnog geen duidelijke keuze gemaakt.

Ontstaan er conflicten tussen de moeders onderling, dan valt met name op dat de positie van de mee-moeder niet is versterkt. Wat zou bijvoorbeeld de uitkomst van de twee eerder besproken adoptiezaken zijn? Ook onder het recht dat is voorgesteld,

\footnotetext{
${ }^{75}$ Zie artikel 1:394 BW.

${ }^{76}$ Zie hierover bijvoorbeeld de voorstellen die Jonker recent in haar boek heeft gedaan. Zij stelt dat de wetgever een onderhoudsplicht in moet voeren voor de bekende donor wanneer het kind alleen een moeder heeft. Jonker, Het recht van kinderen op levensonderhoud: een gedeelde zorg, Familie en recht Deel 3, Den Haag: Boom Juridische Uitgeverij, 2011, p. 309-310.
} 
heeft de mee-moeder toestemming van de moeder nodig om juridisch ouder te worden (via erkenning in dat geval). ${ }^{77}$ Het tweede geval waarin na scheiding op grond van wijziging van omstandigheden vernietiging van een eerder gegeven adoptie beschikking werd verzocht, zou anders aflopen. Stel Vrouw B had prenataal erkend en de relatie werd rond de geboorte beëindigd, dan zou zij er vrijwel zeker niet in slagen de erkenning te laten vernietigen. Alleen al het feit dat haar ouderschap via het afstammingsrecht tot stand is gekomen, geeft de rechter aanzienlijk minder bewegingsruimte. Wordt een dergelijk verzoek namelijk aan een mee-moeder toegewezen, dan kunnen zeer waarschijnlijk ook niet-biologische vaders die door erkenning vader zijn geworden zich op een dergelijke uitspraak beroepen. Gelijkstelling betekent hier dus minder vrijheid.

Wat wel wijzigt, zijn de consequenties van het hebben van gezamenlijk gezag in geval van conflict tussen de vrouwen onderling. In beide besproken zaken hadden de vrouwen gezamenlijk gezag over het betreffende kind en was alleen de moeder juridisch ouder. Het gevolg daarvan is dat het kind niet door de nieuwe partner van de moeder kan worden geadopteerd, omdat de moeder in dat geval eenhoofdig gezag zou moeten hebben of gezamenlijk gezag met haar nieuwe partner. Deze eis geldt bij erkenning niet. Het wordt dus makkelijker voor de moeder om een andere juridische ouder dan de mee-moeder voor haar kind uit te kiezen. In de beide besproken zaken kan de moeder toestemming tot erkenning geven aan haar nieuwe partner, zonder dat haar ex-partner, met wie ze gezamenlijk gezag heeft, daar iets aan kan doen. Dit is tot nu toe niet echt een punt van aandacht geweest, maar de vraag kan gesteld worden of de vrijheid van de moeder om te bepalen wie de tweede ouder wordt van haar kind, hiermee niet te groot wordt. ${ }^{78}$

Een ander punt dat genoemd moet worden is het feit dat in het wetsvoorstel geen regeling over de toegang tot afstammingsinformatie is opgenomen met betrekking tot de kinderen die niet via kunstmatige bevruchting zoals gedefinieerd in de Wet donorgegevens zijn verwekt, maar via zelf- inseminatie met zaad van een al dan niet bekende donor of via kunstmatige inseminatie in het buitenland. ${ }^{79}$ Op verzoek van de Minister is in het rapport Erkenning door de vrouwelijke partner van de moeder

\footnotetext{
${ }^{77} \mathrm{Er}$ is in de Tweede Kamer gevraagd waarom de mee-moeder geen mogelijkheid krijgt vervangende toestemming te verzoeken. Zie Kamerstukken 2011-12 33 032, nr. 5, p 9.

${ }^{78} \mathrm{Zie}$ Kamerstukken 2011-12 33 032, nr. 3, p 5. "Bij een bekende donor besluit de moeder in beginsel wie de juridische ouder wordt van het kind: de bekende zaaddonor of de duomoeder." Maar dit kan dus ook heel wel een derde zijn.

${ }^{79}$ Ook bij adoptie levert het handhaven van het recht op afstammingskennis problemen op. zie bijvoorbeeld rechtbank Roermond, 24 november 2010, LJN BO4992. De moeders in kwestie zijn voor inseminatie naar België gegaan waar een van beide met het zaad van een onbekende donor is geïnsemineerd. Tijdens de adoptieprocedure komt deze handelswijze ter sprake. De rechter stelt dat de moeders in strijd met het recht van het kind op afstammingsinformatie hebben gehandeld. Desalniettemin wijst de rechter het adoptieverzoek toe, omdat het in het belang van het kind is dat zijn sociale situatie overeenkomst met zijn juridische situatie.
} 
uitgebreid op deze materie ingegaan, maar kennelijk is het de wetgever niet gelukt de gedane aanbevelingen in een regeling om te zetten. ${ }^{80}$

Ondanks het feit dat het wetsvoorstel een stap in de goede richting vormt, lijken de rechten en plichten van de mee-moeder en de bekende donor met family life nog niet helemaal in balans te zijn. Met name de positie van de niet-biologische moeder ten opzichte van het kind en de rol die de geboortemoeder in het verkrijgen van juridische status van de niet-biologische moeder speelt, roept vraagtekens op.

\section{Conclusie}

De aandacht voor de juridische positie van kinderen die binnen een lesbische relatie worden geboren, is de afgelopen jaren nauwelijks verslapt. Waar eerst geen regeling voor deze kinderen bestond, is later adoptie mogelijk geworden en wordt nu serieus gesproken over een regeling in het afstammingsrecht. Uit ontwikkelingspsychologisch onderzoek blijkt dat de betreffende kinderen niet meer problemen hebben dan kinderen die in heterorelaties opgroeien, ook waar het de ontwikkeling van hun seksuele identiteit betreft. Daarnaast blijkt dat een grote groep kinderen die geen contact heeft met hun spermadonor later graag informatie zou willen hebben over de persoonlijke kenmerken van hun donor. Het lijkt echter voor het welzijn van de kinderen niet uit te maken of ze met het zaad van een bekende of een onbekende donor zijn verwekt. Wat betreft de verhouding tussen de moeders en hun relatie met het kind, blijkt het al dan niet de geboortemoeder van het kind zijn voornamelijk een rol te spelen in de eerste levensjaren van het kind, maar verdwijnt dit verschil grotendeels naarmate de kinderen ouder worden. Over de meer-oudergezinnen is nog niet veel bekend. Het weinige onderzoek dat tot nu toe is gedaan wijst niet op mogelijke problemen voor de kinderen.

Het besproken wetsvoorstel sluit aan bij de conclusie dat het voor de ontwikkeling van kinderen geen of nauwelijks verschil maakt of ze bij een heteropaar of bij twee moeders opgroeien, door de status van de mee-moeder in het afstammingsrecht te regelen. Dit geeft enerzijds blijk van een streven naar gelijke behandeling van hetero en homoparen en anderzijds van het belang van het kind om in een gezin op te groeien dat juridische erkenning geniet. Of het belang van kinderen bij het kunnen traceren van enige informatie over de man die de helft van hun genetisch materiaal heeft geleverd, voldoende wordt onderkend, blijft een vraag. Ook bij het feit dat de niet-biologische moeder in een aantal gevallen de toestemming van de geboortemoeder nodig heeft om juridisch ouder te kunnen worden kunnen vraagtekens worden gezet. Dit zou met name gevolgen kunnen hebben voor de relatie tussen de twee moeders onderling wat mogelijk niet in het belang van het kind zou zijn. Wat betreft de mogelijkheden voor mee-moeders om samen met een mannenpaar kinderen op te voeden blijft het wetsvoorstel de mogelijkheden bieden die het huidige recht ook biedt.

\footnotetext{
${ }^{80}$ Zie Kamerstukken II 2007-08, 30 551, nr. 22, p. 2. In het eerder genoemde rapport Erkenning door de vrouwelijke partner van de moeder is uitgebreid op het recht op afstammingskennis van het kind ingegaan.
} 